\section{E- LOGOS}

ELECTRONIC JOURNAL FOR PHILOSOPHY ISSN 1211-0442

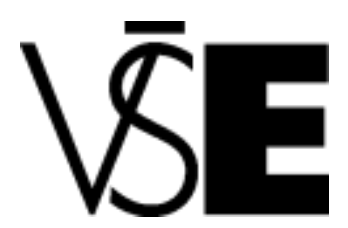

University of Economics

Prague

\title{
Inkorporace metodologického singularismu do metodologie ekonomie
}

Dominik Stroukal

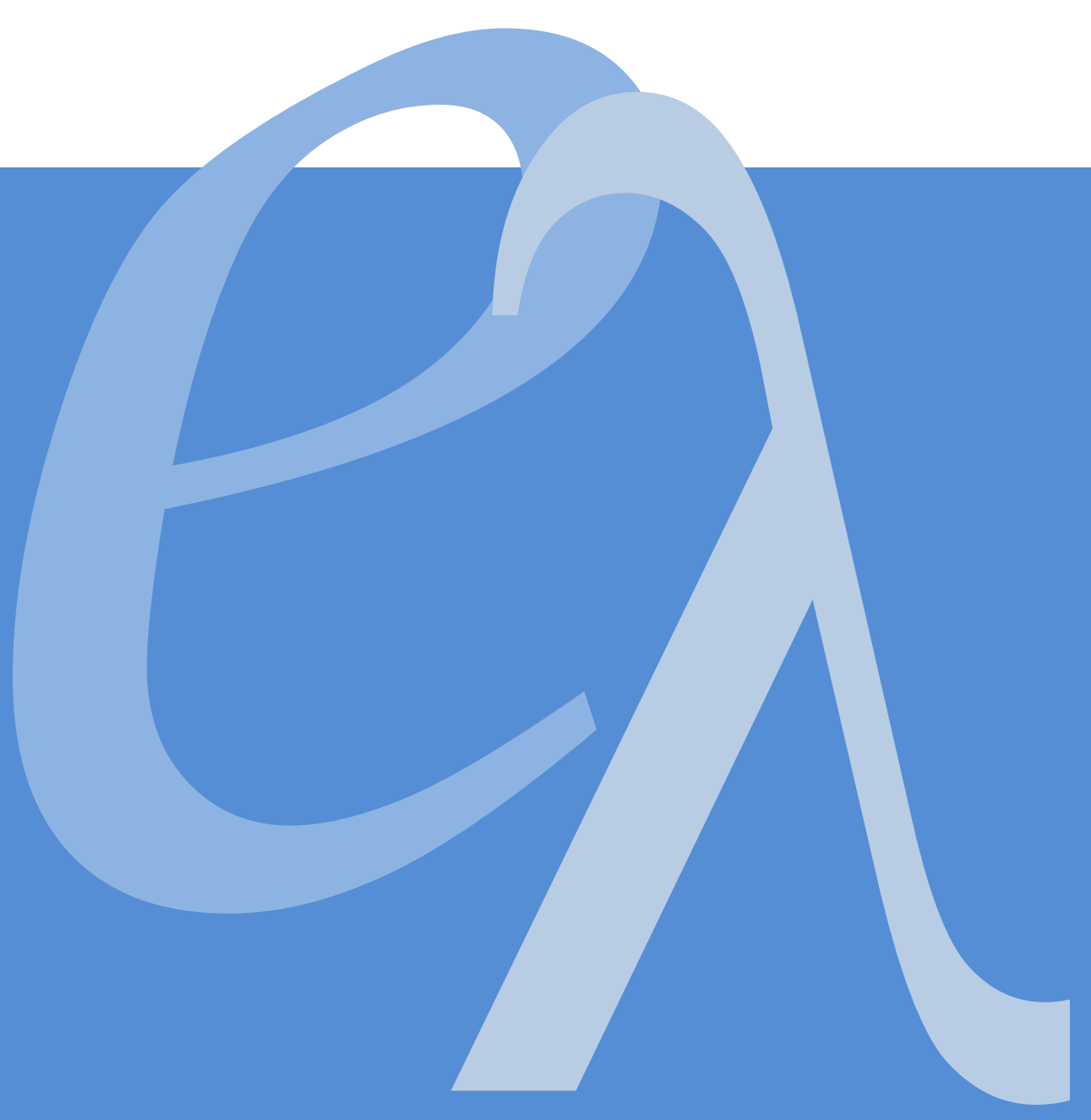




\begin{abstract}
Methodological singularism is one of the four fundamental pillars of Austrian methodology. This work opens up the issue of methodological singularism and argues that it is equally important for economics as are concepts of deduction, methodological individualism and methodological subjectivism. Compliance with methodological singularism is vital because its without it any economic analysis leads to simplification, based on which its conclusions necessarily also become simplified. It is shown that this concept can reject some controversial concepts, i.e. scales of preference, demonstrated preference or indifference curves. Methodological singularismus is a necessary condition to preserve the a priori nature of economics.
\end{abstract}

Keywords: Methodology of economics, methodological singularism, Austrian economics, demonstrated preference, scales of preference.

\title{
Abstrakt
}

Metodologický singularismus je jedním ze čtyř základních piliřů rakouské metodologie. Tato práce otevírá problematiku metodologického singularismu a argumentuje, že je pro ekonomii stejně důležitý jako dedukce, metodologický individualismus a metodologický subjektivismus. Dodržování metodologického singularismu je pro ekonomii zásadní, protože jeho nedodržení vede ke zjednodušení, na základě kterého se závěry ekonomické analýzy stávají nutně taktéž zjednodušenými. Je ukázáno, že tento koncept dokáže zamítnout sporné koncepty preferenčních škál, demonstrovaných preferencí či indiferenčních křivek. Metodologický singularismus je nutnou podmínkou k zachování apriorního charakteru ekonomie.

Klíčová slova: Metodologie ekonomie, metodologický singularismus, rakouská ekonomie, demonstrované preference, škály preferencí. 


\begin{abstract}
„Žádný ekonomický teorém, který není pevně prïpoután ke suým základiom nevyuratitelným retězem uvažováni, nelze považovat za zdravý. Turzeni pronesené bez. tohoto spojeni je arbitrárni a volně se vznáši ve vaduchu. Neni možné zabývat se zulástnim segmentem ekonomie, aniž by ten byl uzavren v úplném systému jednání. (Mises, 2006 [1949], str. 61)“
\end{abstract}

\title{
Úvod
}

Ludwig von Mises jednu z kapitol Lidského jednání nazval „Princip metodologického singularismu“ (Mises, 2006 [1949], stránky 41-42). Tento článek argumentuje, že přestože jde jen o šest krátkých odstavců, význam metodologického singularismu je pro ekonomii zásadní. Bez metodologického singularismu je nekonzistentní a na druhou stranu s jeho pomocí dokáže snadněji vysvětlit některé sporné body teorie.

Rakouští ekonomové ukazují, že praxeologie, potažmo ekonomie, stojí na třech základech. Těmi jsou (v abecedním pořadí); 1) dedukce, 2) metodologický individualismus a 3) metodologický subjektivismus. Všechny tři přístupy jsou dnes považovány za nutnou podmínku $\mathrm{k}$ pochopení ekonomických zákonitostí a je dokazováno, že bez libovolné z nich se ekonomická analýza rozpadá. K nim se přidává požadavek hodnotové neutrality při zkoumání důsledků lidského jednání. O těchto čtyřech přístupech bylo napsáno mnoho prací a jejich význam se výrazně rozšiříil i do ekonomie hlavního proudu.

Jinak je tomu u metodologického singularismu. Od otevření tématu Misesem (2006 [1949]) se mu více než zmínkou věnovali pouze Block a Barnett (2008) a Barnett a Block (2009). Nezodpovězenými otázkami zůstávalo, jak moc je tento př́stup pro ekonomii důležitý a kde je jeho místo. Tyto dvě otázky lze odpovědět současně - tato práce ukazuje, že metodologický singularismus je svou důležitostí srovnatelný s výše uvedenými třemi, jelikož je na jejich úrovni. Pro ty to účely jsou nejprve nadefinovány výše zmíněné tři základy jinak, než je obvyklé $\mathrm{v}$ literatuře věnující se rakouské metodologii, a to pomocí vztahu $\mathrm{k}$ samotnému jedinečnému aktu lidského jednání. Jeli ekonomie odvozena z lidského jednání, je nezbytně nutné, aby ekonomická metodologie s lidským jednáním korespondovala. Následně lze ukázat, že bez metodologického singularismu postrádá metodologie vědy o lidském jednání nástroj pro axiomatickou analýzu samotného aktu jednání.

\section{Metodologie ekonomie}

Chceme-li odvodit metodologii vědy o lidském jednání, je nejprve obecně vhodné a pro účely tohoto článku nezbytné připomenout Misesovu definici lidského jednání: „Lidské jednání je účelové chování. Či jinak řečeno: Jednání je působící vůle uvedená v činnost, směřuje k cílům, je smysluplnou odpovědí ega na podmínky a stimuly z jeho 
prostředí, je vědomým přizpůsobením osoby stavu světa, jenž určuje její život." (Mises, 2006 [1949], str. 11) a tvrzení o ekonomii, která dle Misese „směřuje k rozpoznání důsledků určitých druhů jednání“. (Mises, 2006 [1949], str. 223) V našem případě je důležité, že jednání je lidské, že existuje na základě vůle, tedy rozhodnutí1, a že spolu s dalším jednáním vede $\mathrm{k}$ určitým di̊sledkům, jejichž rozpoznání je cílem ekonomie.

Pokud dáme výše jmenované do logické a jediné myslitelné vzájemné posloupnosti, potom můžeme ukázat, že ekonomie se zabývá procesem, ve kterém (a) člověk na základě (b) vědomého rozhodnutí (c) jedná, což vede (d) spolu s dalším jednáním na základě rozpoznatelných ekonomických zákonitostí k určitým (e) důsledkům.

Toto zjevné rozčlenění nebylo explicitně Misesem ani nikým jiným zmíněno, poskytuje však jednu cennou možnost, kterou jiné př́istupy ke zkoumání metodologie ekonomie neposkytují, tedy možnost zjistit, zda určitý nástroj pro analýzu zkoumaného jevu nechybí. $V$ našem případě, jelikož ekonomii spolu s Misesem považujeme za bezpředpokladovou, axiomatickou vědu, tedy budeme zjišt'ovat, jak ekonomická metodologie odpovídá na otázky, jaký přístup umožňuje axiomatické bezpředpokladové zkoumání (a) jednajícího, (b) rozhodovacího procesu, (c) samotného aktu jednání, (d) ekonomických zákonitostí a (e) jejich důsledků.

Začneme-li od zkoumání přístupu k (a) jednajícímu, lze snadno ukázat, že ekonomická metodologie si již dlouhou dobu osvojila pro tuto část analýzy lidského jednání princip metodologického individualismu. Metodologický individualismus je ve své podstatě ryzím opakem metodologického holismu, tedy souboru různých přístupů považujících za legitimní začínat při zkoumání společenských fenoménů na vyšši úrovni, než je jednotlivec, tedy nejčastěji na úrovni sociálních skupin. Menger (1963, str. 142) říká: „Právě lidská individua a jejich úsilí jsou konečnými elementy naší analýzy...". Ponechme pro nyní stranou individuální úsilí. Jak nás Menger nabádá, měli bychom se při studiu společnosti dívat na jednotlivce. White $(2003$, str. 17$)$ pozorně upozorňuje, že nejde ve skutečnosti o konečné elementy, ale o počáteční bod ekonomické analýzy. Metodologický individualismus je tedy zpo̊sob nazírání na ekonomického aktéra, na fakt, že jednajícím je vždy a výhradně člověk.

$\mathrm{V}$ otázce metodologického přístupu $\mathrm{k}$ (b) rozhodovacímu procesu je situace podobná. Ekonomie se v této části spoléhá na princip metodologického subjektivismu. White (2003, stránky 16-17) ukazuje, že pro Mengera, Misese i Hayeka byl stěžejním metodologickým bodem právě subjektivismus. Metodologický subjektivismus je způsob nazírání na proces rozhodování, na základě kterého člověk jedná. Říká, že člověk se vždy rozhoduje subjektioně a ve vlastním zájmu, at' je jeho zájem jakýkoliv, at' je altruistický, sobecký nebo kdekoliv mezi těmito extrémy. Dále bude ukázáno, že

${ }^{1}$ Mises jinde říká, že “jednání je plodem rozumu” (Mises, 2006 [1949], str. 37) . 
právě Menger, Mises a Hayek zdůrazňovali metodologický subjektivismus, jelikož jím nahrazovali chybějící element v podobě metodologického singularismu.

K problematice metodologického přístupu ke zkoumání (c) samotného aktu jednání totiž metodologie ekonomie mlčí. Fakt, že nejlepším známým a zapomenutým přístupem je Misesův princip metodologického singularismu, bude diskutován dále.

Metodologický přístup ke zkoumání (d) ekonomických zákonitostí, tedy součinnosti jednotlivých jednání, je v ekonomii již dlouho čistě deduktivní. Mises to říká jasně: „Praxeologie, a v důsledku toho rovněž ekonomie, je deduktivní systém. Sílu čerpá z výchozího bodu svých dedukcí, z kategorie lidského jednání." (Mises, 2006 [1949], str. 61)

Poslední otázkou je metodologický přístup k posuzování důsledků jednání. Mises se zásadně zasloužil o zdůraznění principu hodnotové neutrality ve zkoumání ekonomických fenoménů. „Konkrétní lidské soudy a jednání není možné dále analyzovat." (Mises, 2006 [1949], str. 17)

\section{Metodologický singularismus}

Pokud tedy vyjdeme $\mathrm{z}$ předpokladu, že robustní metodologie ekonomie musí vycházet z definice lidského jednání, zjistíme, že se v rámci tradice rakouské školy, jak bylo ukázáno výše, sestává z metodologického individualismu, subjektivismu, dedukce a hodnotové neutrality. Ovšem, to není vše. Z výše uvedeného totiž vyplývá, že praxeologická analýza postrádá ${ }^{2}$ metodu, kterou by přistupovala $\mathrm{k}$ samotnému jednání. Tento článek argumentuje, že tímto př́istupem je metodologický singularismus.

Ilustrujme nejprve na jednoduchém příkladu možný problém ekonomické analýzy při absenci metody přístupu ke zkoumání samotného aktu jednání. Představme si člověka, který dostal na výběr mezi ničím a koláčem, přičemž si dal koláč. Víme, že jde o jednotlivce (díky metodologickému individualismu neanalyzujeme vrstvu lidí, kteří jí koláče), víme, že koláč jí, jelikož se pro to rozhodl na základě subjektivního vnímání př́ležitostí a užitků (a nikoliv proto, že je objektivně „dobré“ jíst koláč) a díky dedukci známe ekonomické zákonitosti, které nám např́íklad říkají, že pokud se cena koláčů zvýší, daný jedinec bude ceteris paribus mít vyšší motivaci tento statek substituovat statkem jiným. Hodnotová neutralita do celé analýzy pak jednoduše vstupuje jako imperativ neposuzovat daného jednotlivce za to, že jí koláč. Představme si, že druhý den je postaven před volbu mezi vajíčky a koláčem a zvolí si vajíčka. Standardní ekonomická teorie zde předpokládá, že tento jednotlivec preferuje vajíčka před koláčem a koláč před ničím. Ekonomové rakouské školy se v tomto bodě výrazně liší od ostatních škol ekonomického myšlení tím, že neváhají upozornit na fakt, že se

\footnotetext{
2 Přinejmenším explicitně, jak bude diskutováno později.
} 
mohly změnit během dne jeho subjektivní preference a proto zvolil jinak. Nyní mohou být jeho preference bez jakýchkoliv pochyb vajíčka>nic>koláč. Předpoklad stabilních preferencí může být užitečným nástrojem historie, nelze však na jeho základě činit $a$ priori závěry. To jediné, co dokáže bezpředpokladová ekonomie o tomto jedinci říct je skutečnost, že první den volil koláč před vším ostatním a druhý den vajíčka před vším ostatním. První den jednal tímto způsobem, druhý den jiným. Tento fakt lze nazvat metodologickým singularismem.

Definice metodologického singularismu však není jednoduchá. Explicitně se metodologickým singularismem zabývalo jen několik prací. Jeden výklad říká, že metodologický singularismus vychází z jednání jako jedinečného a neopakovatelného aktu (Meijer, 1995). Prvními a doposud jedinými autory, kteří se věnují metodologickému singularismu více do hloubky, jsou Block a Barnett (2008). ${ }^{3}$

Ani Mises metodologický singularismus přesně nedefinoval, a je tak přirozené, že bez vlastní definice mohou vznikat rozdílné výklady. Kapitola Metodologický singularismus začíná slovy:

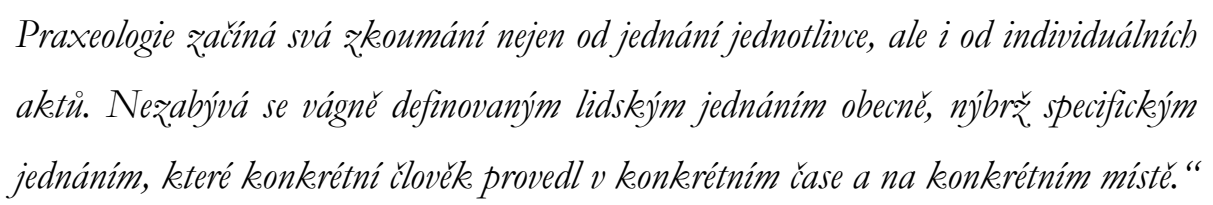

(Mises, 2006 [1949], str. 41)

Barnett a Block (2007, 2008 a 2009) předkládají chápání metodologického singularismu jako nutnou volbu vždy mezi jedním a druhým, bud'/anebo. Dle jejich výkladu Misese je člověk v každém jednání konfrontován se situací volby mezi X a Y. Když je $X$ preferováno před $Y$, tak $Y$ je náklad obětované příležitosti a tedy druhá nejlepší možnost.

Přestože Barnett a Block používají pojem singularismus, upozorňují, že Misesův výběr tohoto slova je "nešt́astný“ (2007, str. 52) či „méně než vhodný“ (2009, str. 9). Navrhovali proto pojmenování metodologický binarismus, jako vyjádření toho, že jednání je vždy volbou mezi dvěma možnostmi, mezi X a Y.

Takový přístup je však neopodstatněný a nekonzistentní. Volbu mezi X a Y nelze pozorovat, lze pozorovat pouze demonstrovanou volbu. Ekonom (a ani nikdo jiný) nemůže pozorovat nevolbu $Y$, pokud člověk zvolil X. Jedinou možnou námitkou je, že druhou možností je všechno ostatní. Metodologický binarismus tak může odkazovat $\mathrm{k}$ volbě $X$ před non- $X$. Taková definice je však nadbytečná. Volba $X$ před non- $X$ je

${ }^{3}$ Block a Barnett (2008) uvádí, že metodologickým singularismem se doposud zabýval pouze Gordon (2003) v přednášce na Ludwig von Mises Institute. 
jednoduše volbou X. Skutečnost, že nebylo zvoleno nic jiného než X, je přímo obsažená ve volbě $X{ }^{4}$

Jak bude ukázáno dále, také skutečnost, že člověk v určitém okamžiku může kvůli specifickým podmínkám volby nebo kvůli fyzikálním zákonitostem světa stát před faktickou volbou mezi X a Y (tedy pokud jediné non-X je Y) není pro ekonomii důležitá, protože ekonom nemůže pozorovat vnitřní uvažování při individuální volbě.

Logickou implikací výše uvedené skutečnosti, že člověk volí mezi jedním a ostatním, respektive že člověk v daný okamžik jedná, své jednání demonstruje (i zdánlivou "nejednáním“, tedy volbou nevolit, což je taktéž spadající pod definici jednání) je metodologický singularismus.

Metodologický singularismus je ve filozofii koncepce, jež přihlíží při určení příčiny jen k aktuální individuální situaci a vymezuje př́ičinu jako souhrn všech událostí, které předcházejí jinou událost, a to tak, že mezi oběma není časová ani prostorová mezera. Jinak řečeno, singularismus se zaměřuje na kauzalitu jako na lokální relaci mezi jedinečnými událostmi. ${ }^{5}$ Block a Barnett k tomuto závěru dochází, když říkají:6

\section{„Dle singularismu se každé lidské jednáni sestává z výbèru jedné možnosti a odmitnutí} v̌sech ostatnich. "(2008, str. 22)

Tento citát lze považovat za nejjednodušší definici metodologického singularismu, avšak stále ponechává výše popsanou nejasnost v otázce „všech ostatních“. V úplném znění, bez této nejasnosti, lze tento koncept tedy nadefinovat takto: Každé lidské jednání se sestává z výběru jedné možnosti a odmítnutí všech ostatních. Ostatní možnosti jsou nedemonstrovatelné, a tím pro ekonomickou analýzu neznámé a irelevantní. Definici je ještě nutné doplnit: Každé lidské jednání se tak sestává z jedinečného aktu jednání. Bez této jedinečnosti by bylo možné uvažovat možnost opakování daného jednání, což je vzhledem k vždy se měnícím okolnostem, přinejmenším již proběhlému předchozímu jednání, nemožné, a šlo by tedy nutně o předpoklad.

Konstatování, že se každé lidské jednání sestává z jedinečného aktu jednání, není, jak se může snad na první pohled zdát, tautologií. Přiblížením může být analogie, kdy výše uvedené konstatování není tautologií ze stejného důvodu, z jakého očividně

\footnotetext{
${ }^{4}$ Zde je vhodné upozornit, že volba $X$ není nutně volbou "koláče“, ale může být i volbou více statků. Volba $X$ je jednoduše aktem volby, jednáním.

${ }^{5}$ Ve filozofii se lze setkat i s kategorizací věd, kdy singularismus označuje vidění světa „z jednoho základu“. Bylo by zajímavé se této filozofické otázce věnovat $\mathrm{v}$ kontextu praxeologie, kde by tím základem mohlo být lidské jednání, jako jediná a dostačující podmínka existence světa. Tento singularismus jde však mimo rámec této práce.

${ }^{6}$ Block a Barnett nekonzistenci v této otázce prokazují např́ič svými články. Přestože docházejí ke správnému závěru, že je možné volit pouze jednu možnost a obětovat všechny ostatní, taktéž uzavírají, že je možné volit mezi X a Y ve smyslu obětování Y (viz např. Block \& Barnett, 2008, str. 17). Takovou obět' ale nelze pozorovat.
} 
není tautologií tvrzení, že každé jablko je jedinečné jablko. Tautologií by bylo tvrzení, že každé jablko je jablko, respektive že každé jednání je jednání. Výše uvedená definice by tedy mohla být zkrácena, možná na úkor srozumitelnosti na:

Každé lidské jednání se sestává z jedinečného výběru jedné možnosti a odmítnutí všech ostatnich, nedemonstrovatelných, a tím irelevantnich pro ekonomickou analýzu.

Spolu s metodologickým singularismem má tedy metodologie ekonomie plný set nástrojů pro ekonomickou analýzu na základě lidského jednání. (a) Metodologický individualismus, jelikož jednajícím může být pouze jednotlivec, člověk; (b) metodologický subjektivismus, jelikož je jeho rozhodování vždy subjektivní; (c) metodologický singularismus, jelikož je akt na základě tohoto jednání jedinečným aktem, o kterém nelze bez předpokladů říci více než to, že k aktu došlo; (d) dedukci, díky které se dají z více jedinečných aktů odvodit ekonomické zákonitosti a (e) hodnotovou neutralitu jako doplňující požadavek. Tyto vztahy přehledně ukazuje diagram v př́iloze.

\section{Implikace a diskuze}

\section{Škála preferencí}

Z pohledu ekonomické analýzy je vztah metodologického singularismu a škály preferencí zajímavým tématem. Tuto problematiku otevřeli Barnett a Block (2009), když označili preferenční škálu za koncept odporující metodologickému singularismu. ${ }^{7}$ Pokud je pak metodologický singularismus pro ekonomii nutnou podmínkou, je škála preferencí konceptem, který nemá v ekonomii místo.

Škála preferencí ukazuje ve své ordinalistické verzi pořadí možností volby, jejichž počet je omezen pouze známými možnostmi. Mưže se tedy stát, že člověk volí mezi krávou, koněm a rybou. Na své škále preferencí řadí nejvýše krávu, potom koně a nejníže rybu. Takový člověk potom konfrontován se situací volby mezi těmito třemi zvolí krávu.

Rakouští ekonomové upozorňují, že škála preferencí je nutně omezena na daný čas jednání. Je však nemožné volit v jednom čase více než jednou. Tento fakt pak do důsledku vede $k$ tomu, že škála preferencí se nejen může měnit v každém čase (a proto je potřeba zavést koncept demonstrovaných preferencí), ale také může z pohledu pozorujícího ekonoma obsahovat nanejvýš jeden prvek, tedy zvolené jednání. I z pohledu metodologického binarismu by mohla obsahovat pouze dva prvky, $X$ a nonX. Přestože je možné i u dvou prvků mluvit o „škále“, je pojem „preferenční škála“ již

\footnotetext{
7 Je však nutné mít na paměti, že Block a Barnett označují pojmem „metodologický singularismus“ ve skutečnosti metodologický binarismus. Jejich závěry ukazují, že škála preferencí nemá smysl, ani pokud uvažujeme volbu mezi dvěma možnostmi, což pouze posiluje závěry vyplývající ze silnějšího konceptu, metodologického singularismu, který je zde představen a obhajován.
} 
historicky nadefinován jako množina, která může obsahovat i více prvků, a jako takový ho nemá smysl zachovávat. Nadto, jak bylo ukázáno výše, metodologický binarismus ve formě $X$ a non-X je nadbytečný a do jisté míry zavádějící koncept. Přijetí metodologického singularismu tak implikuje maximálně jednoprvkovou škálu a tudíž je koncept škály preferencí nekonzistentní s ekonomickou metodologií. Jde o nutně zjednodušující model lidského jednání a jako takový nemá v praxeologické analýze smysl.

Možným protiargumentem je otázka, zda odmítnutí preferenčních škál není v rozporu s principem metodologického subjektivismu. Námitka zní, že jedinec si může kreslit škály preferencí, mít je v hlavě a rozhodovat se dle nich. Takovou námitku je však snadné odmítnout. Je pravdou, že je otázkou každého jednotlivce, na základě čeho se rozhoduje, zda si před volbou hází mincí či zda se řídí dle proměnlivých nebo pevných preferenčních škál. Je dokonce možné uvažovat, že každý člověk se rozhoduje tak, že má na mysli škálu preferencí a volí nejvýše postavené jednání, jednání, které mu přinese nejvyšší uspokojení. Nicméně metodologický singularismus nic podobného nevylučuje. Co vylučuje, je využití preferenčních škál jako východiska pro ekonomickou analýzu. Ekonom nemůže škály preferencí pozorovat a i kdyby je kdokoliv vyjmenoval, nelze je užít k jakékoliv analýze, jelikož jde pouze a jen o hypotetické pořadí nutně podléhající $\mathrm{v}$ čase změnám a nedemonstrovaných a nedemonstrovatelných skutečným jednáním.

\section{Demonstrované preference}

Na základě výše uvedeného je také možné blíže zkoumat Rothbardův koncept demonstrovaných preferencí. Rothbard se implicitně potýkal s problémy, které absence metodologického singularismu přináší. Všimnul si, že ekonom nemůže považovat projevené preference za důvěryhodné, jelikož nebyly demonstrovány jednáním. K tomu Rothbard ř́íá:

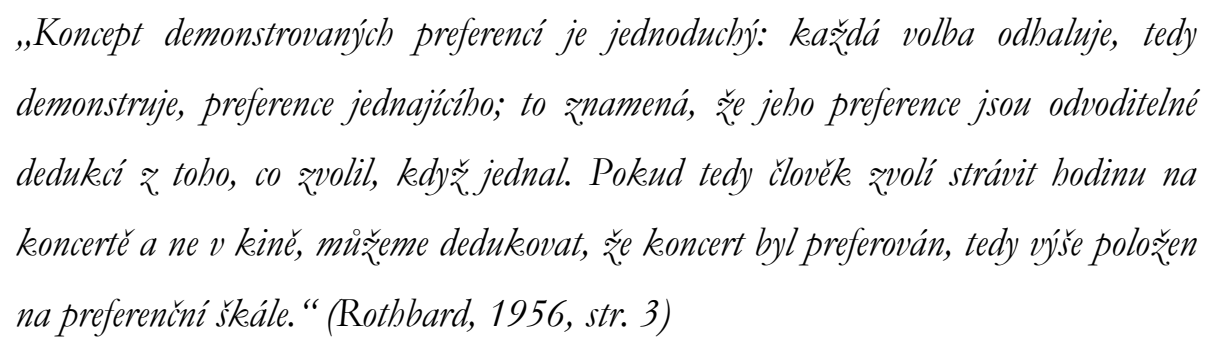

Protože je škála preferencí nepoužitelná, je tato pasáž opět zavádějící. Pokud člověk volí mezi koncertem a kinem, ekonom nemůže tuto volbu pozorovat, protože nevolba kina nebyla demonstrována. Nevolbu nelze demonstrovat, protože nelze pozorovat rozhodování. Ekonom nemůže odlišit možnosti, které nebyly zvoleny od možností, které nebyly ani do rozhodování zahrnuty. Pokusy o to jsou nutně zjednodušováním a porušením konceptu metodologického singularismu. Preference nelze 
demonstrovat. Metodologický singularismus upravuje koncept demonstrovaných preferencí do konceptu demonstrované volby či ještě lépe demonstrovaného jednání.

Podíváme-li se na Rothbardův koncept demonstrovaných preferencí blíže, lze jasně vidět, že Rothbard svými demonstrovanými preferencemi neodstranil ani problém projevených preferencí v podobě hypotetizování možných situací, které ve skutečnosti nenastaly, ani problém stability preferencí. Pokud nelze souhlasit s konceptem projevených preferencí, kdy jsou individuální preference vyloženy a následně jsou považovány za dlouhodobě stabilní, potom proč bychom měli uvažovat stabilní preference krátkodobě? A jaký existuje důvod pro jakkoliv krátkou dobu, po kterou bychom měli tyto preference za stabilní považovat? A u hypotetických situací také zůstal problém; pokud jsou projevené preference jen hypotetickými preferencemi, které by v dané situaci ve skutečnosti nemusely být demonstrovány, potom to samé platí i pro všechna nedemonstrovaná jednání na škále i u demonstrovaných preferencí. Vrátíme-li se k Rothbardem výše uvedenému příkladu, zařazení kina na škálu preferencí a jeho nevolba je stejně hypotetická jako možnosti u projevených preferencí. Jediné jednání a jediná možnost, která není hypotetická, je možnost, která byla zvolena, tedy demonstrována. Vše ostatní je shodné s konceptem odhalených preferencí. Zůstává tedy pouze demonstrované jednání, což je zcela v souladu s metodologickým singularismem, respektive jde o jednoznačný a jediný možný závěr po inkorporaci tohoto konceptu do metodologie ekonomie.

\section{Indiference}

Teorie indiference byla i bez vědomé aplikace metodologického singularismu rakouskými ekonomy již vyvrácena. Ekonomická analýza na základě indiferenčních křivek byla podrobena kritice především Rothbardem (1956). Tato kritika stojí na rozporu s výše popisovanou teorií demonstrovaných preferencí. Stručně řečeno, i pokud by byl člověk mezi některými volbami indiferentní, ekonom nemůže tuto indiferenci pozorovat, protože nebyla demonstrována.

Metodologický singularismus poskytuje proti konceptu indiferenčních křivek jinou a možná i pevnější kritiku, jelikož neexistence indiference se stává praxeologickým (tedy nevyvratitelným) faktem. Singularismus říká, že člověk se rozhoduje tak, že rozhodnutí je v každém jednání definitivní. Indiference v jednání se tedy př̌ičí singularismu. Indiference je tedy ex definitione nemožná.

Je však nutné reagovat na námitku, že se člověk v životě často setkává s případy nerozhodnosti, například pokud je nerozhodný mezi cestou vlakem a autobusem. Taková nerozhodnost může být způsobena, z ekonomického hlediska, dvěma důvody. Zaprvé může jít o dva stejné statky. Pokud se člověk potřebuje dostat z bodu A do bodu B a je mu jedno, zda se přepraví vlakem či autobusem, protože oboje považuje za dva statky z jedné zásoby statku „doprava z bodu A do bodu B“, jde o stejnou situaci, jako když člověk vytahuje arašídy ze sáčku, tedy je mu jedno, který konkrétní vytáhne, 
protože jde o zásobu stejných jednotek daného statku. V takovém př́ípadě nedělá člověku problém si zvolit mezi dvěma možnostmi například jízdu autobusem, protože nejde o volbu. Protože nejde o nerozhodnost mezi dvěma různými statky, potom nelze hovořit o indiferenci. Naopak, nerozhodnost mezi jednotkami stejných statků je z definice podmínkou jakékoliv zásoby statků.

Druhou možností je situace, kdy se jedná o dva různé statky, mezi kterými se člověk nemůže rozhodnout. Pokud člověk považuje vlak i autobus za různé statky (kvůli různému „mixu“ rychlosti, komfortu, přestupů a jiných charakteristik), potom se může stát, že je mezi nimi nerozhodný. $\mathrm{V}$ takovém př́ípadě dochází $\mathrm{k}$ tomu, co Rothbard popisuje na příkladu Buridanova osla:

„Protože obě kupky sena jsou stejnè atraktivni ve všech smèrech, osel si nemüže vybrat a zemre hlady. (...) Osel v̌̌ak ve skutečnosti neni postaven pred dvě možnosti, ale trí, tou trétíje nevybrat si a umř̀t blady. (...)Pokud jsou obě kupkey sena stejnè atraktivní, potom osel či clověke, který mezi nimi musi zuolit, prìstoupi na nábodné rozhodnutí, napríklad pomocí hodu mincí, aby si mezi nimi vybral. " Rothbard, 1956, stránky 10-11)

Rothbard situaci ale poněkud nesprávně nazývá třetí možností. Počet možností a možnosti samotné mohou být libovolné a různé v jiném čase. Osel může uvažovat pro pozorovatele neviditelné možnosti nebo i možnosti fakticky neuskutečnitelné (nevybrat si a neumř́t hlady).

Co je důležité, je skutečnost, že ekonom $v$ obou případech pozoruje demonstrovanou volbu, demonstrované jednání. Není a nemůže být podstatné, z jakých důvodů a za jakých okolností. Pokud se člověk rozhodne náhodně, hodem mincí, po dnech přemýšlení nebo jen intuitivně, vždy nakonec demonstruje pouze jednu volbu, jedno jednání. Rothbardův př́istup je psychologizující. Při absenci metodologického singularismu (a tedy nemožnosti odmítnutí indiference z definice) se musel Rothbard vrátit (viz grafické znázornění v př́loze) od jednání k rozhodování. Zde, aby dokázal neexistenci indiference, musel porušit metodologický subjektivismus a přiřknout ekonomovi schopnost pozorovat rozhodování. Ekonom nemůže pozorovat rozhodování, ale výhradně rozhodnutí, tedy jednání. Pokud si osel zvolil smrt, není pro ekonomickou analýzu podstatné proč nebo mezi čím se rozhodoval. Taková informace může být zajímavá pro analýzu psychologickou či historickou, ale nikoliv ekonomickou.

\section{Robustnost metodologického singularismu}

Pochopitelnou námitkou je otázka robustnosti celého konceptu. Tím máme na mysli skutečnost, že je metodologický singularismus nadbytečný, případně dokonce pro 
ekonomickou analýzu škodlivý, tedy jeho přínos je horší než žádný. Obě námitky mají pevný základ a je nutné se s nimi vypořádat.

Začněme rovnou námitkou, že je inkorporace metodologického singularismu do metodologie ekonomie škodlivá. Tato námitka je založena na poznání, že důsledné lpění na principu metodologického singularismu podstatně zužuje záběr ekonomie a zejména zcela zásadně omezuje šiři závěrů ekonomické analýzy. A skutečně, i při letmém pohledu na závěry ekonomických článků, at' hlavního proudu či článků $\mathrm{v}$ rakouské tradici, lze prakticky u všech nalézt dřive či později porušení metodologického singularismu. Odmítnutí závěrů těchto článků však není cílem této práce a kvůli zachování těchto závěrů není nutné odmítnout metodologický singularismus.

Tato práce si neklade a ani nemůže klást za cíl edukaci ekonomů do té míry, že by přestali užívat indiferenční analýzu, preferenční škály etc. Závěrem této práce je upozornění na nevědomky vkládané předpoklady do míst, kde kvůli neúplné ekonomické metodologii část autorů předpoklady neuvažuje. Zjednodušeně řečeno, pokud autor užívá preferenční škály, nemůže své závěry považovat za apriorní, přestože by na všech ostatních místech analýzy postupoval apriorně.

Nelze popřít, že důsledné lpění na metodologickém singularismu by omezilo prostor, ve kterém může ekonomie popsat společnost, otázkou zůstává, zda jde o pozitivní či negativní skutečnost. Nicméně na tomto místě lze pouze uzavřít, že samotné poznání důležitosti metodologického singularismu nemusí být nutně špatné, naopak, přidává ekonomické analýze na důvěryhodnosti, pokud se již taková analýza snaží důvěryhodnost získat skrze apriorní postup.

Otázka nadbytečnosti metodologického singularismu vyplývá především ze skutečnosti, že i bez uvědomění si jeho existence se ekonomická analýza, v tomto případě zejména v rakouské ekonomické tradici, rozvíjela a přinášela solidní výsledky (Rizzo, 2009) a to i na poli metodologie ekonomie, kde byly některé implikace metodologického singularismu představeny i bez explicitní znalosti tohoto konceptu. Jak bylo ukázáno výše, např́klad v otázce indiferenčních křivek bylo možné jejich podstatu zavrhnout i na základě aplikace jiných metod, zde konkrétně pomocí zavedení konceptu demonstrovaných preferencí, který i přes svou nekonzistenci dokázal přijít ke stejnému výsledku, jako metodologický singularismus, který indiferenci popírá z definice.

Na tuto námitku je odpověd' relativně snadná, uvážíme-li samotnou snahu o vědecké poznání na základě jednodušších konceptů či modelů. Lze-li ke stejnému závěru dojít skrze aplikaci vnitřně konzistentního a jednoduchého konceptu anebo vnitřně rozporného a složitějšího, potom dává smysl přiklonit se k prvnímu z těchto dvou. 


\section{Závěr}

Zkoumání důsledků metodologického singularismu je v současnosti otevřenou otázkou. $V$ této práci byly některé možné důsledky naznačeny a popsány, je však jasné, že metodologický singularismus má důsledků mnohem více.

Dodržování metodologického singularismu je pro ekonomii zcela zásadní, protože každé jeho nedodržení vede ke zjednodušení, na základě kterého se závěry ekonomické analýzy stávají také nutně zjednodušenými. Má-li ekonomie jako součást praxeologie nevyvratitelně popisovat důsledky lidského jednání, musí zůstat apriorní a konzistentní v každé části analýzy.

Je možné, že z úvodního výčtu piliřro rakouské metodologie se může metodologický singularismus jevit jako podřadný, méně důležitý. Je možné argumentovat, že analýza jednání jako výběru mezi první a druhou nejlepší možností není stejně zásadní, jako zbývající tři, tedy dedukce, metodologický individualismus a metodologický subjektivismus.

Na druhou stranu lze argumentovat, že možnou se tato kritika stává právě jen kvůli historickému podcenění její důležitosti. Stejně jako Menger (1950 [1871]) zanechal ve své analýze preferencí kardinální užitek, tak následovníci Misese zanechali ve svých analýzách škálu preferencí. Bylo ukázáno, že metodologický singularismus má $\mathrm{v}$ ekonomické analýze své místo a dokáže z vlastní definice vysvětlit některé problémy, na které rakouská ekonomie delší dobu upozorňuje.

Důsledkem metodologického singularismu je tak odmítnutí nejen teorie indiference, teorie projevených preferencí či jistě i jiných, rakouskými ekonomy odmítnutých konceptů a teoríi. Důsledkem je i odmítnutí konceptů a teorií samotnými rakouskými ekonomy používaných, at' již jde o představené odmítnutí škály preferencí, nebo jiných, které je patrně možné ještě nalézt, pokud se člověk na některé sporné otázky podívá skrze tento staronový koncept. 


\section{Bibliografie}

Barnett, W. I., \& Block, W. (2007). On Hayekian Triangles. Review of Austrian Economics, Vol. 20, No. 1, stránky 43-61.

Barnett, W. I., \& Block, W. (2008). Economic Categorization. Laissez Faire, No. 28-29, stránky 4-12.

Barnett, W. I., \& Block, W. (2009). Scale of values violates singularism. Dialogue, Vol. 3, stránky 81-91.

Block, W., \& Barnett, W. I. (2008). Economic Singularism. Research in the History of Economic Thought and Methodology, Volume 26-A, stránky 15-30.

Gordon, David. (2003). Epistemological problems of economics. Získáno 24.12 2010, z Audio recording. Ludwig von Mises Institute: http:/ / mises.org/ resources/2091

Meijer, G. (1995). New perspectives on Austrian economics. Routledge.

Menger, C. (1950 [1871]). Principles of Economics. (J. Dingwall, \& F. H. Bert, Editoři) Clencoe: Free Press.

Menger, C. (1963). Problems of Economics and Sociology. Urbana: University Illinois Press,.

Mises, L. (2006 [1949]). Lidské jednání. Praha: Liberální institut.

Rizzo, M. J. (2009). Austrian Economics: Recent Work. V New Palgrave Dictionary of Economics. Londýn: Palgrave Macmillan.

Rothbard, M. N. (1956). Toward a Reconstruction of Utility and Welfare Economics. V M. Senholz (ed.), On Freedom and Free Enterprise: The Economics of Free Enterprise. D. Van Nostrand.

White, L. (2003). The Methodology of the Austrian School Economists. Auburn: Ludwig von Mises Institue. 


\section{Př́loha - Metodologie ekonomie}

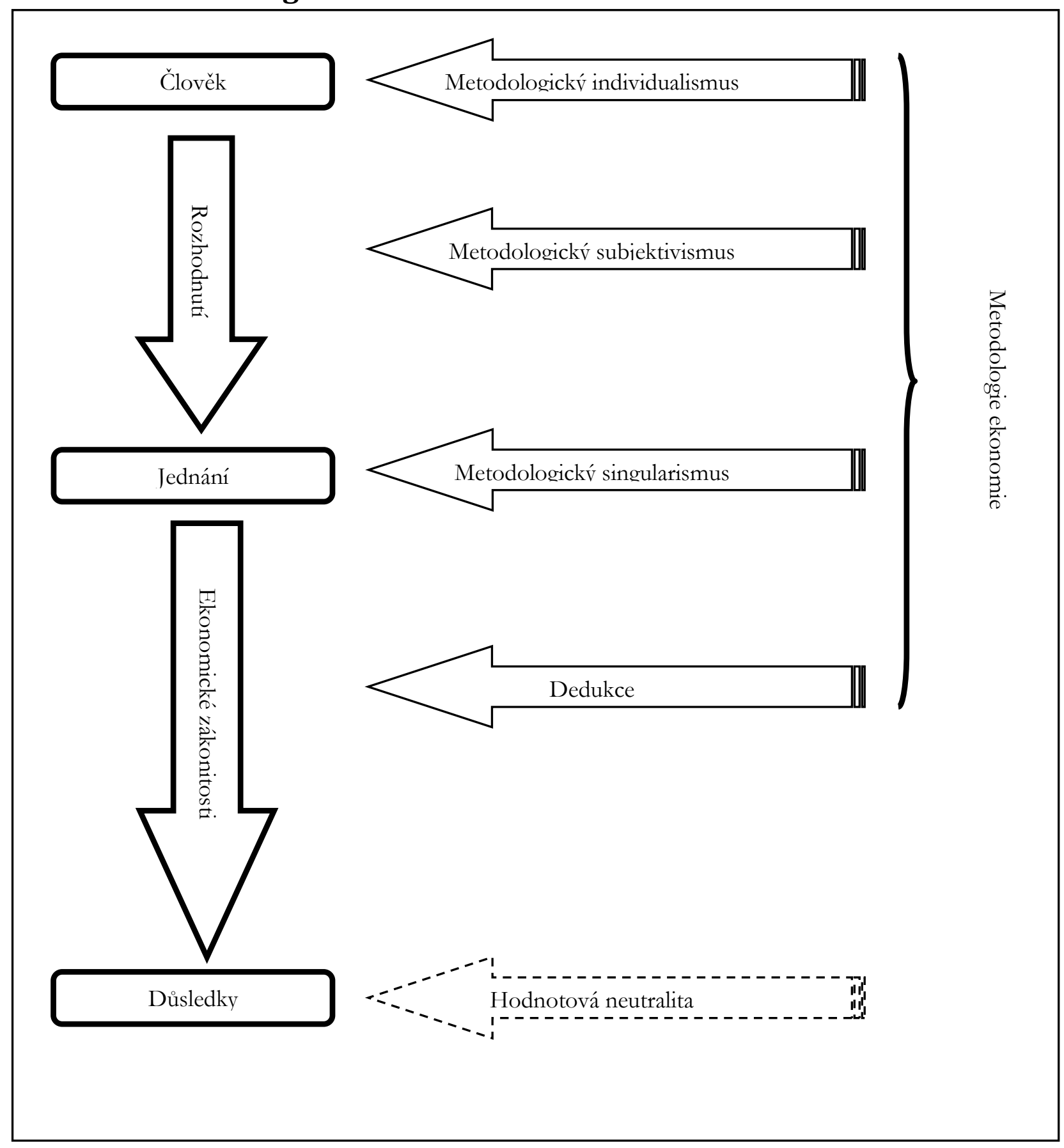




\section{E- LOGOS}

\section{ELECTRONIC JOURNAL FOR PHILOSOPHY}

Ročník/Year: 2014 (vychází průběžně/ published continuously)

Místo vydání/Place of edition: Praha

ISSN 1211-0442

Vydává/Publisher:

Vysoká škola ekonomická v Praze / University of Economics, Prague

nám. W. Churchilla 4

Czech Republic

13067 Praha 3

IČ: 61384399

Web: http://e-logos.vse.cz

Redakce a technické informace/Editorial staff and technical information:

Miroslav Vacura

vacuram@vse.cz

Redakční rada/Board of editors:

Ladislav Benyovszky (FHS UK Praha, Czech Republic)

Ivan Blecha (FF UP Olomouc, Czech Republic)

Martin Hemelík (VŠP Jihlava, Czech Republic)

Angelo Marocco (Pontifical Athenaeum Regina Apostolorum, Rome, Italy)

Jozef Kelemen (FPF SU Opava, Czech Republic)

Daniel Kroupa (ZU Plzeň, Czech Republic)

Vladimír Kvasnička (FIIT STU Bratislava, Slovak Republic)

Jaroslav Novotný (FHS UK Praha, Czech Republic)

Jakub Novotný (VŠP Jihlava, Czech Republic)

Ján Pavlík (editor-in-chief) (VŠE Praha, Czech Republic)

Karel Pstružina (VŠE Praha, Czech Republic)

Miroslav Vacura (executive editor) (VŠE Praha, Czech Republic) 